\title{
MODEL PENDIDIKAN ISLAM BAGI LANSIA DI DAARUT TAUHIID BANDUNG
}

\author{
Siti Maryam, * \\ EndisFirdaus, Kokom St. Komariah \\ Program Studi Ilmu Pendidikan Agama Islam \\ Fakultas Pendidikan Ilmu Pengetahuan Sosial, Universitas Pendidikan Indonesia \\ *E-mail : siti.maryam@gmail.com
}

\begin{abstract}
ABSTRAK
Pendidikan tidak terbatas oleh usia, sehingga tidak menutup kemungkinan bagi lansia untuk menambah ilmu kembali, khususnya ilmu agama. Akan tetapi, pendidikan lansia itu berbeda dengan pendidikan lainnya. Warga belajar usia lanjut memiliki berbagai kesulitan dalam menerima suatu materi. Hal itu disebabkan karena terjadinya berbagai kemunduran, seperti kognitif, fisik dan psikologis. Oleh karena itu, maka peneliti merasa tertarik untuk melakukan penelitian dengan judul “Model Pendidikan Islam bagi lansia di Daarut Tauhiid Bandung". Penelitian ini bertujuan untuk mengetahui 1. perencanaan, 2. pelaksanaan dan 3. hasil pendidikan Islam di Daarut Tauhiid. Peneliti memilih Daarut Tauhiid (DT) Bandung, karena DT adalah salah satu lembaga yang mewadahi para lansia untuk menginput ilmu agama dalam waktu singkat namun intensif. Pada penelitian ini pula, peneliti menggunakan metode deskriptif dengan pendekatan kualitatif. Teknik pengumpulan data yang digunakan adalah wawancara, observasi dan studi dokumentasi. Adapun untuk perencanaan, para pengurus merancang kurikulum yang dibuat sendiri, kalender pendidikan dan segala sesuatu yang berkaitan dengan kegiatan pendidikan Islam pada program PMK. Sedangkan pelaksanaannya yaitu proses kegiatan belajar mengajar yang materinya disesuaikan dengan kebutuhan lansia. Selain itu, proses pendidikan Islam bukan hanya didapatkan dari kegiatan belajar mengajar saja, akan tetapi dari pembiasaan ibadah, kedisiplinan, dan lingkungan sekitar. Sedangkan, hasil dari proses pendidikan Islam yaitu adanya perubahan diri baik dari wawasan, akhlak ataupun keterampilan. Adapun hasil lainnya, yaitu sangat memotivasi lansia untuk senantiasa mendekatkan diri kepada Allah dengan harapan mencapai ḥusnul khātimah.
\end{abstract}

Kata kunci : Pendidikan Islam; Lanjut Usia (Lansia); dan Daarut Tauhiid. 


\section{PENDAHULUAN}

Pendidikan merupakan bagian yang tidak dapat dipisahkan dari hidup dan kehidupan manusia. Bagaimanapun, kapanpun dan dimanapun manusia memerlukan pendidikan. Maka dalam pengertian umum, kehidupan manusia akan selalu ada aktivitas pendidikan di dalamnya. Sebab, pendidikan secara alami sudah merupakan kebutuhan hidup manusia (Ramayulis, 2012, hal. 28).

Islam tidak mengenal batas akhir dalam menempuh pendidikan. Hal tersebut mengingat tujuan yang ingin dicapai dalam pendidikan Islam adalah terbentuknya akhlākul karimaћ. Pembentukan itu membutuhkan rentang waktu yang panjang yaitu sepanjang hayat manusia. Konsep ini pula yang diterapkan dalam sistem pendidikan Islam, konsep pendidikan tanpa batas usia. Setiap individu dibebankan kewajiban untuk menerima pendidikan sepanjang hayatnya. Pendidikan sepanjang hayat berarti bahwa pendidikan orang dewasa dan orang tua juga bisa menjalani proses pendidikan (Umar, 2010, hal. 218).

Sejalan dengan hal tersebut, salah satu misi dari pendidikan Islam menyatakan bahwa pendidikan Islam melaksanakan kegiatan belajar mengajar sepanjang hayat. Hal ini sejalan dengan hadits nabi Muhammad saw,

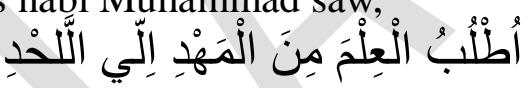

Artinya : "Tuntutlah ilmu mulai dari buaian hingga liang lahat"

Hadits tersebut mengandung isyarat tentang konsep belajar mengajar tidak hanya terbatas pada ruang kelas saja, melainkan dimana saja dan dalam berbagai kesempatan (Nata, 2012, hal. 46).

Akan tetapi, jika suatu lembaga mengadakan pendidikan lansia, maka harus diperhatikan pula perkembangan pada usia lanjut. Sebagaimana menurut Yusuf dan Sughandi (2011, hal. 114)menjelaskan bahwa masa lanjut usia (lansia) ditandai dengan semakin melemahnya kemampuan fisik dan psikis. Pada umumnya mereka mengalami penurunan kemampuan dalam aspek pendengaran, penglihatan, daya ingat, cara berpikir dan berinteraksi sosial. Pada usia ini pula, seseorang dimungkinkan akan mengalami masa pikun, masa kembali ke usia anak-anak, yang bersifat dependent (tergantung) kepada orang lain.

Dengan adanya hal tersebut, maka warga belajar lansia akan mengalami beberapa kesulita saat menerima suatu materi. Selain itu, hasil survey memberikan data bahwa para lansia mengalami berbagai kesulitan dalam menerima materi. Telas jelas, bahwa hal itu disebabkan karena pada masa lansia ini adanya berbagai kemunduran, seperti kemunduran biologis, psikis dan sosial. Sebagaimana (Tim Pengembang Ilmu Pendidikan, 2007, hal. 146)kelemahan yang dihadapi para lansia adalah sulitnya menghubungkan materi yang telah diterima pada masa lalu dengan materi yang baru diterimanya. Hal tersebut disebabkan karena menurunnya daya ingat usia lanjut. Karena daya ingat yang semakin menurun, para lansia memerlukan waktu yang lama untuk mengingat. Selain itu, ada faktor lain yang mempengaruhi proses pembelajaran usia lanjut, seperti faktor fisiologis, faktor psikologis, faktor lingkungan belajar dan faktor sistem penyajian.

Oleh karena itu, maka penulis merasa perlu untuk meneliti tentang pendidikan Islam bagi lansia pada program pesantren masa keemasan (PMK) di Dārut Tauhīd. Berdasarkan hasil survey menjelaskan bahwa PMK ini adalah salah satu program unggulan Pesantren Dārut Tauhīd yang dilaksanakan selama 40 hari. Program ini dikhususkan bagi para lanjut usia yang ingin memperdalam ilmu agama dan lebih mendekatkan diri kepada Allah agar 
bisa mencapai husnul khātimaћ. Jadi, bukan hanya penyampaian materi saja, akan tetapi ada juga pembiasaan ibadah wajib ataupun sunnah.

Adanya pendidikan Islam bagi lansia, merupakan gebrakan baru yang harus didukung dan dikembangkan. Pendidikan lansia ini, arahnya bukan untuk mengarahkan para lansia sebagai mubalig. Akan tetapi, adanya pendidikan Islam lansia ini isinya lebih kepada praktis agama, memecahkan permasalahan keagamaan yang dihadapi oleh lansia, dan lain sebagainya. Selain itu, pendidikan Islam ini menjadi penting dalam rangka memenuhi kebutuhan para lansia di usia 50 tahun sebagai upaya menambah wawasan keagamaan dan mendekatkan diri kepada Allah dengan harapan bisa mencapai husnul khātimaћ.

\section{METODE}

Metode yang digunakan dalam penelitian ini adalah metode deskriptif. Dengan menggunakan metode deskriptif maka peneliti menggambarkan gejala yang ada di lapangan, seperti aktivitas, perubahan hubungan atau fenomena lainnya. Sebagaimana Fathoni (2006, hal. 97) menjelaskan metode deskriptif itu adalah metode yang bermaksud mengadakan pemeriksaan dan pengukuran-pengukuran terhadap gelaja tertentu.

Adapun pendekatan yang digunakan dalam metode ini adalah pendekatan kualitatif. Sehingga data yang dihasilkan adalah data dalam bentuk kata-kata hasil penelitian.

Sebagaimana Bodgan dan Taylor(dalam Basrowi \& Suwandi, 2008, hal. 21)menjelaskan bahwa pendekatan kualitatif itu sebagai prosedur penelitian yang menghasilkan data deskriptif berupa kata-kata tertulis atau lisan dari orang-orang dan perilaku yang diamati.

Menurut Sukardi (2013, hal. 53-55) menjelaskan bahwa subjek yang akan diambil dalam penelitian biasanya disebut sebagai populasi. Populasi pada prinsipnya adalah semua anggota kelompok manusia, binatang, peristiwa, atau benda yang tinggal bersama dalam satu tempat dan secara terencana menjadi target kesimpulan dari hasil akhir suatu penelitian.

Adapun yang menjadi subjek dalam penelitian ini adalah orang-orang yang paham dengan segala kegiatan/aktivitas pendidikan Islam pada program pesantren masa keemasan. Selain itu, mereka juga harus mengetahui latar belakang adanya program PMK. Oleh karena itu, yang menjadi subjek penelitian ini adalah ketua Darut Tarbiyah, pengurus, alumni PMK dan lansia/santri yang mengikuti kegiatan pendidikan Islam pada Program Pesantren Masa Keemasan Dārut Tauhīid.

Jadi, peneliti sebagai instrumen atau alat yang paling utama harus memahami apa yang akan diteliti dan dikaji dalam penelitiannya. Selain itu, peneliti juga harus mampu membaca dan memahami segala aktivitas, situasi dan kondisi objek dan subjek penelitian.

Sejalan dengan pendapat tersebut, bahwa peneliti dalam penelitian kualitatif merupakan perencana, pelaksana pengumpulan data, analisis, penafsir data, dan pada akhirnya ia menjadi pelapor hasil penelitiannya. Pengertian instrumen atau alat penelitian tersebut tepat karena ia menjadi segalanya dari keseluruhan proses penelitian. Adapun ciri-ciri umum manusia sebagai instrumen pada penelitian kualitatif yaitu responsif, dapat menyesuaikan diri, dan lain sebagainya (Basrowi \& Suwandi, 2008, hal. 173).

Sedangkan untuk teknik pengumpulan data, peneliti menggunakan teknik observasi, wawancara, studi dokumentasi dan triangulasi. Dengan menggunakan teknik tersebut, sangat membantu peneliti dalam pengumpulan data penelitian.

Setelah mendapatkan data, peneliti melakukan analisis data, dengan tiga tahap yaitu reduksi data, display data dan 
conclution

drawing/kesimpulan.

Sebagaimana Miles dan Huberman (dalam Sugiyono, 2013, hal. 337) menjelaskan bahwa ada tiga tahapan yang harus dikerjakan dalam menganalisis data penelitian kualitatif, yaitu reduksi data (data reduction), paparan data (data display), dan penarikan kesimpulan/verifikasi (conclusion drawing/verifying).

Reduksi data diartikan sebagai proses pemilihan, pemusatan perhatian pada penyederhanaan, pengabstrakan, dan transformasi data kasar yang muncul dari catatan-catatan tertulis di lapangan. Reduksi data merupakan bagian dari analisis. Pilihan-pilihan peneliti tentang bagian data mana yang dikode, mana yang dibuang, pola-pola mana yang meringkas sejumlah bagian yang tersebar dan cerita apa yang sedang berkembang, semuanya itu merupakan pilihan-pilihan (Sutopo \& Arief, 2010, hal. 11).

Pada tahap reduksi data, peneliti memilih data yang merupakan bagian penting dari hasil penelitian. Agar memudahkan peneliti, maka dalam reduksi data peneliti menggunakan koding data. Peneliti memberikan koding berdasarkan kategorisasi data yang diperoleh seperti koding untuk teknik pengumpulan data (Wawancara $=\mathrm{W}$, Observasi $=\mathrm{O}$ dan Dokumen $=$ Dok). Adapun koding dalam kategorisasi umum penelitian ini seperti Perencanaan (PR), Pelaksanaan (PL) dan Hasil (HL).

Langkah selanjutnya adalah menyajikan data (data display). Dalam penelitian kualitatif, penyajian data bisa dilakukan dalam bentuk uraian singkat, bagan, hubungan antar kategori dan lain sebagainya. Selain itu, data yang sering digunakan untuk menyajikan data dalam penelitian kualitatif dengan teks yang bersifat naratif (Sugiyono, 2013, hal. 341).

Pada tahap pemaparan data, peneliti memaparkan hasil reduksi data sesuai dengan rumusan masalah penelitian. Pada paparan data ini, peneliti memaparkan terlebih dahulu hasil penelitian lapangan. Setelah itu, dipaparkan pula hasil penelitian yang kemudian dikaitkan dengan teori.

Langkah ke tiga dalam analisis data kualitatif adalah penarikan kesimpulan dan verifikasi. Kesimpulan awal yang dikemukakan masih bersifat sementara, dan akan berubah bila tidak ditemukan bukti-bukti yang kuat yang mendukung pada tahap pengumpulan berikutnya. Tetapi apabila kesimpulan yang dikemukakan pada tahap awal, di dukung oleh bukti-bukti yang valid dan konsisten saat peneliti kembali ke lapangan mengumpulkan data, maka kesimpulan yang dikemukakan merupakan kesimpulan yang kredibel(Sugiyono, 2013, hal. 345).

Analasis data yang terakhir adalah kesimpulan. Peneliti, menyimpulkan hasil analisis data sesui dengan rumusan masalah penelitian.

\section{HASIL DAN PEMBAHASAN}

1. Analisis Perencanaan Pendidikan Islam Bagi Lansia pada Program Pesantren Masa Keemasan

\section{PMK}

Hasilpenelitianmenjelaskanbahwa

adalahsalahsatupendidikannonformal yang dilaksanakanolehpihakDārutTarbiyah.

Dalam proses perencanaan, para pengurusmembuatkurikulumsebagaikera ngkaacuandari program PesantrenMasaKeemasan. Kurikulum yang digunakanadalahkurikulum yang dibuatolehpihakpengurusDārutTarbiyah. Adapunisikurikulumitumencakuplatarbel akang, tujuan, output program, namakegiatan, sasarankegiatan, syaratsantri yang inginmengikuti PMK, metodologipembelajaran,

tahapankegiatan,

kebutuhansumberdayamanusia, fasilitas, kerjasamadenganpihaklain, materimateri, danpenutup (WRB dan Dok.1). 
Menurut (Suprijanto, 2008, hal. 8) menjelaskan bawha pendidikan nonformal adalah kegiatan belajar yang disengaja oleh warga belajar dan pembelajar di dalam suatu latar yang diorganisasi (berstruktur) yang terjadi di luar sistem persekolahan. Pendidikannonformal, sekurangkurangnyamempunyaiciricirisebagaiberikut

merupakanpendidikanluarsistempersekol ahan, (2) jarangberjenjang, dan (3) tidakketatketentuan-ketentuannya.

Jadi, telahjelasbahwa program PMK merupakanpendidikan Islam nonformal. Hal tersebut, ditandaidenganciriciribahwa PMK adalah program pendidikan yang berstruktur, namuntidakmengikutiaturan-aturan yang tetapdanketat. Program PMK jugamerupakanpendidikanluarsistempers ekolahan. Selainitu, denganadanyakurikulummembuktikande nganjelasbahwa program PMK adalahadalahpendidikan Islam nonformal yang

berstrukturatauterorganisasidenganbaik.

Menurut (Umar, 2010, hal. 165) bahwa suatukurikulumituterdiriatasbeberapako mponen, yaitutujuan, isi, metodeatau proses belajar-mengajardanevaluasi. Setiapkomponendalamkurikulumtersebut sebenarnyasalingberkaitan,

bahkanmasing-masingmerupakanbagian integral darikurikulumitusendiri.

Para pengurus PMK sudah seharusnya membuat kurikulum yang disesuaikan dengan kebutuhan para santri PMK (lansia). Dengan adanya kurikulum, maka pendidikan Islam pada PMK ini terencana dengan jelas baik dari segi tujuan, materi dan metode yang digunakan. Kurikulum yang dibuat oleh pengurus sudah cukup baik, karena komponen yang ada dalam kurikulum PMK mencakup, komponen penting seperti, tujuan, materi, metode, tahapan kegiatan dan lain sebagainya.
Selainkurikulum, para pengurusjugamembuatkalenderpendidika n. Adanyakalenderpendidikanini, untukmempermudahpengurusuntukmelak sanakan program selamasatutahunkedepan. Jadi, dalamsatutahuninipengurustinggalmelaks anakanapa yang telahdirencanakandandijadwalkansebelu mnya. Kalenderpendidikan yang dibuatolehpengurus, merupakanpenjadwalan program yang ada

DārutTarbiyahselamasatutahunkedepan.

Denganadanyahaltersebut,

makajelasakanlebihmemudahkanpenguru s agar diantarasatu program dengan yang lainnyatidaksalingberbentrokan.

Perencanaanini, biasanyadilaksanakan di akhirtaunyaitusebelumpelaksanaanrapatk erja (raker). Jadi, beberapaminggusebelumraker, pihakperencanaandanpengembanganmer encanakan program selamasatutahunkedepan.

Padasaatterlaksananyaperencanaanb ulanan, hal-hal yang direncanakanadalahsegalasesuatu yang berkaitandenganpendidikan Islam pada program PMK, sepertibentukkegiatan yang akandilaksanakan, menentukanmateridanpemateri yang berkompeten di bidangnya, menentukantempatdan lain sebagainya. Terkaitdengandenganpemateridantempat pelaksanaan yang dilaksanakan di luarlingkungan DT, biasanyadikonfirmasibeberapamingguseb elumkegiatan.

Selainitu, para pengurusjugamerancangberbagaikegiatan Pendidikan Islam pada program PMK. Ada beberapakegiatan yang didalamnyaberlangsung proses pendidikan Islam, sepertimasaorientasi, kegiatanbelajarmengajar, tafakkuralam, danpersiapanmenujuhariakhirbahagia (PMAHB). Sedangkanregistrasi, wawancaradantes al-Qur`ān, 
evaluasidanwisudamerupakankegiatanpe nunjangpada program PMK. (1994,

Menurut Kamal Muhammad Isa 15)perencanaanadalahsuatupemikiran yang mantap. Kajiankhususterhadapsuatupekerjaan yang dilakukan, agar bentukdantahappelaksanaannyadapatberj alanmenurutgaris yang telahditentukandenganjelas.

Perencanaandanpersiapanmasadepan, merupakanamalIslami. Al-Qur'ān pun selalumenganjurkanpadasetiapmuslim agar mauberpikirdanbermusyawarah, untuksetiappekerjaan yang ingindilakukannya.

Berdasarkanpenjelasan di atas, penelitimenyimpulkanbahwaperencanaan pendidikan Islam pada program PMK telahdilakukandengancukupbaik.

Perencanaan

dilaksanakansudahcukupterorganisir.

Hanyasaja,

padaperencanaankurangadanyainovasi.

Perludiingatkembali,

bahwaadanyaevaluasibagi para santri PMK, dimaksudkan agar setiap saran hasilevaluasibisaditindaklanjuti. Akan tetapi, para pengurusbelumterlalumemperhatikantind aklanjutdarihasilevaluasitersebut.

Sehingga, program dirancangmengikutialursajatanpaadanyai novasi. Hal inidisebabkankarena, banyaknya program dansumberdayamanusia yang adahanyasedikit, sebagaimana yang telahdituutrkanolehbagianrencanadanpen gembangan.

2. Analisis Pelaksanaan Pendidikan Islam pada Program Pesantren Masa Keemasan

Berdasarkanhasilpenelitian, pelaksanaanpendidikan Islam pada Program

PesantrenMasaKeemasandilaksanakansel ama 40 hari. Secarakeseluruhan, tujuan para santrimengikutikegiatanini, untukmemperdalamilmu agama daninginlebihmendekatkandirikepada Allah agar bisamencapaihusnulkhātima (WAL, WS2, WS3).

Adapun kegiatan rutin selama mengikuti PMK, dimulai dari pukul 03.00 untuk melaksanakan salat tahajjud. Akantetapi, biasanya pada pukul 02.00 pun santri PMK sudah bangun dan secara bergiliran memasuki kamar mandi untuk bersiap-siap melaksanakan salat tahajjud di asramanya masing-masing. Kemudian pada pukul 04.30 santri PMK melaksanakan salat subuh berjamaah di masjid. Padapukul 05.00-06.00 santri PMK mendengarkan MQ on air. Setelah itu, pada pukul 06.00-08.00 adalah kegiatan pribadi santri (makan, mandi dan lain sebagainya (Dok.8 dan OPB1).

Pada pukul 08.00 dimulailah kegiatan belajar mengajar (KBM) sampai pukul 09.30. Pukul 09.30-10.00 santri istirahat sejenak dan jika ada yang belum melaksanakan salat dhuha, maka pada waktu itulah santri PMK melaksanakan salat dhuha. Kemudian, pada pukul 10.00-11.30 santri melaksanakan KBM kembali dan pada pukul 11.30-12.30 santri melaksanakan salat dzuhur berjamaah di masjid. Untuk kegiatan siang hari yaitu pukul 12.30-15.00, merupakan kegiatan pribadi santri seperti, makan dan istirahat sejenak sebelum kegiatan KBM dimulai kembali (Dok.8, OBS1 dan OBS2).

Sedangkan untuk sore hari, setelah santri melaksanakan salat ashar berjamaah yaitu pada pukul 15.30-16.30 dimulai kembali KBM sesuai dengan materi yang telah dijadwalkan oleh pengurus. Berakhirlahkegiatan KBM dandilanjutkandenganpersiapansalatmagr ibberjamaah di masjid. Proses pelaksanaanpendidikan Islam padapesantrenmasakeemasanini, berlangsungdarihariseninsampaijum'at. Sedangkanuntukharisabtu, kegiatannyahanyasenamlansiabagi para 
Bundadan jogging bagi para Ayah (Dok.8 dan OBS3).

Dibawahiniakandipaparkantahapanp elaksanaankegiatanpendidikan Islam, dimulaidariregistrasisampaidenganwisud a/pelepasan :

\section{a. Registrasi}

Kegiatan ini dilaksanakan pada hari pertama dan bagi santri yang belum melakukan registrasi secara langsung maka haru mengisi form yang telah disediakan oleh pengurus.

\section{b. Ekspektasi dan tes al-Qur'ān}

Adapun untuk hari kedua, para santri melakukan wawancara dan tes al-Qur'ān. Berdasarkan hasil wawancara dengan bagian renbang, wawancara ini diajukan untuk mengetahui tujuan dan harapan mengikuti pendidikan Islam pada program PMK. Sedangkan tes al-Qur'ān dilaksanakan agar saat pembelajaran alQur’ān berlangsung, terarah dan terencana dengan baik. Sehingga adanya tes ini, agar dapat dikelompokkan sesuai dengan kemampuannya masing-masing.

\section{c. Masa Orientasi}

Adanya masa orientasi, untuk memperkenalkan lembaga yang mengadakan program PMK ini, yaitu Yayasan Dārut Tauḥīd dan unit Dārut Tarbiyahћ khususnya. Selain itu, dipaparkan pula penjelasan tentang program PMK, baik dari latar belakang, tujuan dan lain sebagainya. Pada masa orientasi ini pula, pihak operasional sebagai pelaksana mengingatkan kepada para santri untuk meluruskan niat, bahwa tujuan mengikuti kegiatan pendidikan Islam pada program PMK ini untuk memperdalam ilmu agama.

Tujuan ialah suatu yang diharapkan tercapai setelah sesuatu atau kegiatan selesai. Maka pendidikan, karena merupakan suatu usaha dan kegiatan yang berproses melalui tahap-tahap dan tingkatan-tingkatan, tujuannya bertahap dan bertingkat. Tujuan pendidikan bukanlah suatu benda yang berbentuk tetap dan statis, tetapi ia merupakan suatu keseluruhan dari kepribadian seseorang, berkenaan dengan seluruh aspek kehidupannya (Darajat dkk, 2009, hal. 29).

\section{d. Kegiatan Belajar Mengajar}

Pada kegiatan belajar mengajar, ada beberapa materi yang diterima oleh santri selama kegiatan pendidikan Islam. Materi-materi yang dimaksud adalah sebagai berikut :

\section{1) Ma'rifatullah/Tauhid}

Materi ini disampaikan agar para santri lebih mengenal dan mengetahui Sang Pencipta. Pada saat pematerian, disampaikan keutamaan mengenal Allah, sifat-sifat yang dimiliki Allah, dan menyatakan pula bahwa pondasi dari agama itu adalah mengenal Allah dan tunduk serta patuh kepada Allah dan Rasul-Nya (OBS2).

\section{2) Fiqh}

Materi fiqh disampaikan dengan luwes dan disertai dengan contoh dalam Materi fiqh ini dimulai dari pengantar fiqh ibadah, fiqhțhārah, fiqh salat1 dan 2ebagainya. Materi disampaikan mulai dari yang mudah sampai kepada materi yang kompleks (OBS1).

\section{3) Al-Qur'ān}

Untuk pembelajaran Al-Qur'ān dibagi menjadi tiga kelompok, yaitu $i \grave{h s} \bar{a} n$, pra taḥsin dan tahsinn. Akan tetapi, untuk Ayah hanya dua kelompok yaitu pra taḥsin dan tahsiñ. Pengelompokkan sesuai dengan kemampuan masingmasing. Kelompok iḥsān adalah kelompok bagi para santri PMK yang membaca iqra' tapi huruf-hurufnya masih tertukar. Kalau pra tahsin , ia sudah masuk kalimat tapi masih agak sedikit lambat, ada yang masih tertukar hurufnya dan tajwidnya pun masih belum benar. Akan tetapi, ia masih bisa dibetulkan bacaannya. Kalau taḥsin, ia sudah sempurna maksudnya, membacanya sudah bagus, huruf tidak ada yang 
tertukar hanya tinggal menyempurnakan saja (WPA1, WMS dan OBS5).

4) Akhlak (Manajemen Kalbu)

Materi akhlak yang disampaikan kepada para santri lebih menekankan tentang manajemen kalbu. Disampaikan pula materi tentang karakter BAKU (Baik dan Kuat) yang merupakan tujuan dari program ini. Adanya materi ini, berharap agar santri dapat memadukan dua karakter yaitu baik dan kuat. Karakter baik itu seperti rendah hati, jujur, tulus, ikhlas dan lain sebagainya. Sedangkan kuat adalah disiplin, gigih, cerdas, ulet, tangguh dan lain sebagainya (OBS3 dan OBS4).

5) Tujuh Cinta

Materi tujuh cinta ini adalah cinta ilmu, cinta Al-Qur'ān, bahaya cinta dunia, cinta zikir dan do'a, cinta shadaqah, cinta masjid, dan amal-amal yang mendatangkan cinta Allah. Dengan adanya materi ini, para santri dapat mengetahui esensi dari Al-Qur 'ān, dunia, zikir dan do'a, sedekah, masjid, dan amalan-amalan baik. Dengan mengetahui semua itu, diharapkan para santri bisa mencintai dan mengamalkan amalan yang baik juga bisa bermanfaat bagi diri sendiri serta lingkungannya (OBS5 dan OBS6).

Menurut (Tim Pengembang Ilmu Pendidikan, 2007, hal. 146) menjelaskan bahwa bahan ajar (materi) dapat disusun dengan beberapa acuan, yaitu sebagai berikut : suatu materi disusun sedemikian rupa, dimulai dari materi yang sederhana, kemudian meningkat kepada materi yang lebih kompleks. Materi juga disusun sedemikian rupa sehingga memungkinkan peserta didik dapat mempelajarinya dimulai dari keseluruhan, kemudian sampai pada bagian-bagiannya. Selain itu, materi disusun secara berurutan, agar peserta didik melakukan kegiatan belajar dengan langkah yang berurutan pula. Dengan merumuskan materi berdasarkan prinsipprinsip tersebut, memungkinkan tumbuhnya pengalaman belajar yang diikuti selama kegiatan pendidikan berlangsung.

Selain itu, berdasarkan teori prinsip tentang bahan ajar (materi), menyimpulkan bahwa materi yang disusun oleh para pengurus sudah cukup baik dan tanggapan dari para santri (lansia) terkait materi, dirasa sudah cukup dan sesuai dengan apa yang mereka butuhkan. Prinsip pertama, bahwa materi disusun dari materi yang sangat mudah sampai materi yang lebih kompleks. Pada materi KBM, materi yang diberikan sudah mencakup materi pertama. Contohnya, pada materi fiqh, yang dibahas pada pertemuan pertama bukanlah tentang fiqh zakat, akan tetapi dimulai dari dasar yaitu materi fiqh ibadah. Materi yang disampaikan, tidak secara umum tapi sampai kepada bagianbagiannya dan disampaikan secara berurutan. Dengan penerapan prinsip tersebut maka, salah satu materi yang sangat melekat dan menumbuhkan pengalaman bagi santri adalah materi manajemen kalbu.

Diperjelas dengan teori tersebut, bahwa pendidikan yang diberikan bagi orang dewasa (lansia) harus disesuaikan dengan situasi, kondisi dan kebutuhannya. Pendidikan Islam inilah yang masih dibutuhkan oleh para santri PMK. Materi yang dirancang oleh pengurus adalah materi yang telah disesuaikan dengan kebutuhan para lansia, sehingga para lansia pun sudah merasa cukup dengan materi yang telah diterima oleh mereka selama mengikuti kegiatan PMK.

Selain materi KBM, perlu diperhatikan pula metode yang digunakan oleh pengajar. Secara keseluruhan metode yang digunakan saat KBM berlangsung adalah metode ceramah, tanya jawab dan simulasi. Sedangkan untuk tanya jawab, berlangsung selama proses KBM. Adapun simulasi, tergantung pada

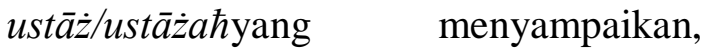
karena tidak semua pengajar 
menggunakan metode tersebut. Adapun media yang digunakan adalah power point sesuai dengan kreatifitas masingmasing pengajar.

Sebagaimana yang telah dipaparkan diatas, metode yang biasa digunakan saat kegiatan belajar mengajar pendidikan Islam pada program PMK adalah metode ceramah. Metode ceramah adalah suatu cara penyampaian informasi melalui penuturan secara lisan oleh pendidik kepada peserta didik(Ramayulis, Ilmu Pendidikan Islam, 2012, hal. 281).

Sejak mencapai usia kedewasaan hingga ke usia sekitar 50 tahun, perkembangan fisik manusia boleh dikatakan tidak mengalami perubahan yang banyak. Barulah diatas usia 50 tahun mulai terjadi penurunan perkembangan yang drastis hingga mencapai usia lanjut akhir. Oleh karena itu, umumnya garis perkembangan pada periode ini digambarkan oleh garis menurun. Sejalan dengan penurunan tersebut, maka secara psikis terjadi berbagai perubahan pula. Perubahanperubahan gejala psikis ini ikut mempengaruhi berbagai aspek kejiwaan yang terlihat dari pola tingkah laku yang diperlihatkan (Jalaluddin, 2010, hal. 109).

Dengan menggunakan metode ceramah, maka penyampaian materi dilakukan hanya satu arah. Akan tetapi, dibantu dengan metode lain yaitu adanya metode tanya jawab. Selama KBM, santri aktif bertanya kepada pengajar, terutama tentang permasalahan yang dihadapi dalam kehidupan sehari-harinya. Dengan metode ceramah juga, terkadang ada beberapa santri yang mengantuk saat KBM berlangsung. Sehingga, para pengajar harus mencari metode lain yang relevan dengan lanjut usia. Maksudnya, metode yang digunakan selama KBM sebaiknya, tidak ceramah dan tanya jawab saja tapi mencari metode lain yang bisa menggugah semangat yang lebih bagi para santri.
Selain itu, sebaiknya pada akhir pembelajaran ustāż/ustā̇za mengulang kembali pokok materi yang telah disampaikan, hal itu bertujuan agar para santri mengingat pokok-pokok materi yang disampaikan oleh ustā̇/ustāża . Akan tetapi, para santri pun terkadang mencatat materi yang penting dan tidak ada dalam modul. Hal itu, dilakukan agar bisa membuka kembali catatan-catatan peting dari materi yang disampaikan.

Selain materi KBM, para santri harus melaksanakan pembiasaan, seperti pembiasaan salat tahajjud, puasa, salat berjamaah dan lain sebagainya. Lingkungan pun sangat mendukung untuk melaksanakan ibadah baik fardu ataupun sunnah. Memang ada beberapa santri PMK yang tidak bisa berpuasa dan tidak salat berjamaah ke masjid, hal itu karena keadaan yang tidak memungkinkan. Akantetapi, secara keseluruhan santri PMK dapat membiasakannya dengan baik (WS1, WS4, dan WS5).

Sebagaimana dijelaskan bahwa latihan pengalaman dimaksudkan sebagai latihan penerapan secara terus menerus, sehingga peserta didik terbiasa melakukan sesuatu sepanjang hidupnya. Misalnya, membiasakan salat, dipraktikkan langsung dalam rangka melaksanakan kewajiban pada waktu dan tempat yang tepat (Syahidin, 2009, hal. 137-138).

Dengan adanya pembiasaan, merupakan aplikasi dari perlunya mengamalkan kebaikan yang telah diketahui. Proses pendidikan Islam bagi lansia, menekankan pengalaman dan latihan agar senantiasa melekat pada diri lansia. Jadi, adanya pembiasaan (pengalaman dan latihan) sangatlah penting dalam proses pendidikan Islam bagi lansia. Perlu digaris bawahi bahwa muslim yang seutuhnya, bukan hanya mendekatkan diri kepada Allah saja, akantetapi ia juga menjalin hubungan dengan sesama manusia dan alam sekitar. Hal tersebut, ditemukan pada para santri 
PMK, selain mendekatkan diri kepada Allah mereka pun menjalin hubungan yang sangat bagus dengan sesama dan masyrakat sekitar.

Sedangkan untuk materi kepesantrenan, yang rutin berjalan setiap minggunya adalah MQ On Air, kajian muslimah ahad, tausiyah senin pagi, kajian al-Hikam, pengajian ma'rifatullah, dan kajian ba'da magrib. Karena materi kepesantrenan ini disampaikan bagi khalayak umum sehingga bisa disebut dengan ceramah umum (OBS2 dan OBS6).

Menurut (Ramayulis, 2012, hal. 38).pendidikan Islam dapat dirumuskan sebagai proses transinternalisasi pengetahuan dan nilai Islam kepada peserta didik melalui upaya pengajaran, pembiasaan, bimbingan, pengasuhan, pengawasan dan pengembangan potensinya, guna mencapai keselarasan dan kesempurnaan hidup di dunia dan akhirat.

Sejalan dengan teori tersebut, bahwa proses pendidikan Islam pada program PMK adalah kegiatan transinternalisasi nilai-nilai Islam, melalui bimbingan, pengarahan dan pembiasaan yang diarahkan kepada kebaikan, guna untuk menuju kesempurnaan. Selain itu, adanya pengarahan perkembangan manusia, baik dari segi akal, tingkah laku, kehidupan sosial ataupun keagamaa. Jadi, proses pendidikan Islam bagi lansia ini, bukan hanya penyampaian materi saja. Akan tetapi, adanya pengalaman dan latihan (pembiasaan) yang rutin. Selain itu, proses pendidikan Islam bukan hanya menambah wawasan, tapi mengarahkan juga kepada perubahan tingkah laku, kehidupan sosial dan kebiasaaankebiasaan.

\section{e. Tafakkur Alam}

Kegiatan tafakkur alam dimulai pukul 08.15, sampailah para santri di tempat tujuan. Kemudian, mereka langsung berkumpul dan kegiatan dibuka bersama-sama dengan membaca do'a.
Adapun untuk kegiatan pertama adalah games, yang dipimpin oleh pak Adrianto. Kegiatan games ini, dibuka dengan pelatihan konsentrasi. Adapun untuk permainan pertama, para santri PMK bermain dengan bola kecil yang terbuat dari kertas. Sedankan, untuk permainan kedua, yaitu bermain dengan tali rapia yang akandibuat dalam berbagai berntuk.

Setelah acara games, para santri segera masuk ke Masjid untuk melaksanakan salat duha. Waktu terlaksananya salat duha dimulai pada pukul 09.00-09.45. Pada pukul 09.4510.00 diisi dengan relaksasi dan hafalan Q.S. ar-Rahmmān secara bersama-sama. Kemudian, pada pukul 10.00-11.00 adanya penyampaian materi dari Ustā $\dot{z}$ Maulana. Setelah itu, para santri melaksanakan salat zuhur berjamaah. Pada pukul 12.30-12.50 dilaksanakan makan bersama dan pada pukul 13.00 santri melakukan perjalan pulang untuk kembali ke Dārut Tauhīd. Selesailah kegiatan Tafakkur alam ini dan para santri PMK pun beristirahat di asramanya masing-masing (OTA).

Menurut Haidar Putra Daulay (2009, hal. 12) menjelaskan bahwa pendidikan Islam adalah pendidikan yang bertujuan untuk membentuk pribadi muslim seutuhnya, mengembangkan seluruh potensi manusia baik yang berbentuk jasmaniyah maupun rohaniyah, menumbuhsuburkan hubungan yang harmonis setiap pribadi manusia dengan Allah, manusia dan alam semesta.

Dengan adanya kegiatan tafakkur Allah, merupakan salah satu realisasi kegiatan dari tujuan pendidikan Islam. Kegiatan tafakkur alam, selain untuk mempererat hubungan dengan Allah, kegiatan ini pula yang mempererat hubungan satu sama lain. Akan tetapi, walaupun ada games ringan yang menyenangkan bagi para santri, masih ada beberapa yang dirasa masih kurang. Menurut peneliti, karena tema kegiatan adalah tafakkur alam maka yang harus 
ditonjolkan adalah kegiatan tafakkur alamnya. Sehingga, pada kegiatan ini sebaiknya materi yang disampaikan bukan dalam bentuk KBM seperti biasanya. Akan tetapi, bisa disetting dengan kegiatan sederhana yang berkaitan dengan tafakkur Alam.

\section{f. Persiapan Menuju Hari Akhir Bahagia (PMAHB)}

Pada tanggal 14 April 2015, kegiatan PMAHB dimulai pukul 02.40 dini hari. Peneliti berangkat pada pukul 02.00 untuk melihat kegiatan muhasabah dan salat tahajjud berjamaah. Sesampainya di lokasi, peneliti melihat para santri PMK sudah bangun dan bersiap-siap untuk melaksanakan salat tahajjud berjamaah. Pada pukul 03.00 dimulailah salattahajjud bersama. Selesainya salat tahajjud, pengurus membagikan syal kepada para santri PMK untuk menutup matanya masing-masing. Setelah itu, para santri menyusuri jalan menuju aula MC dengan keadaan mata tertutup karena menggunakan syal. Para pengurus mengawasi dan membantu para santri sampai memasuki aula MC.Di aula muslimah center ini, para santri duduk dan Ustā̇z pun memulai kembali renungan untuk bermuhasabah diri. Dengan adanya muhasabah ini, menyadarkan para santri PMK agar lebih baik dalam berucap dan bersikap, bersyukur atas segala nikmat yang telah diterima dan tidak mengulang kesalahan yang pernah dilakukan. Selain itu, menyadarkan pula bahwa Allah Maha segalanya, tidak ada tempat lain untuk berlindung selain Allah (OPB1).

Kemudian, Ustā̇ memberikan kesempatan untuk berdo'a kepada masing-masing santri sambil merenungi setiap kejadian yang telah dialaminya. Tangisan para santri PMK bergema dalam ruangan aula MC. Ada salah satu dari Ayah, menangis dan berteriak memohon ampun serta meminta maaf kepada kedua orangtuanya karena belum bisa membahagiakan mereka. Suasana yang sangat membuat terharu, sedih, takut dan betapa diri ini belum ada apaapanya serta jauh dari kesempurnaan. Beberapa menit kemudian, Ustā $\dot{z}$ menyuruh para santri untuk melepas syal nya masing-masing. Setelah itu lampu aula center menyala kemudian para santri PMK bermusafahah saling bermaafan(OPB1).

Adapun dalam segi rohani, manusia dapat dibedakan sesuai dengan kepercayaan atau agama yang dianutnya. Selain itu, dengan segala kelebihan yang dimilikinya manusia akan mengetahui pula keterbatasan dirinya. Sehingga tumbuhlah pada diri manusia bahwa yang maha segalaNya adalah Allah. Manusia hanya makhluk biasa dan tidak mempunyai makna tanpa adanya Sang Pencipta yaitu Allah swt,. Kebutuhan makhluk akan Khalik, sama sekali tidak bisa dihindarkan. Makhluk sebagai ciptaan, bagaimanapun sangat tergantung kepada Sang Pencipta (Khalik). Hubungan manusia dan agama merupakan hubungan yang bersifat kodrati. Agama itu sendiri menyatu dalam fitrah penciptaan manusia (Jalaluddin, 2010, hal. 159).

Dengan adanya muhasabah diri, merupakan salah satu bentuk kegiatan yang menunjukkan bahwa manusia akan selalu butuh akan agama, karena pengaruh agama bisa memberikan ketenangan. Kebutuhan ini harus dipertajam dengan ibadah. Dengan adanya hal tersebut, maka hubungan antara makhluk dengan Sang Khaliknya tidak bisa dihindarkan, karena kebutuhan akan agama, berkaitan pula dengan butuh pada Khaliknya. Kegiatan muhasabah ini, sangat baik untuk meningkatkan kesadaran diri agar senantiasa mendekatkan diri kepadaNya.

Pada hari kedua, kegiatan ini dimulai pada pukul 10.00 dengan materi tentang pengurusan jenazah dan pematerinya adalah Ustāża Siti Sumarni. Media yang 
digunakan adalah power point. Adapun alat yang digunakan yaitu segala sesuatu yang berkaitan dengan pengurusan jenazah. Sebelum memulai praktik pengurusan jenazah, pemateri memaparkan secara singkat Al-Qur'ān dan $h \bar{a} d \bar{i} \dot{s}$ yang berkaitan dengan pengurusan jenazah. Selain itu, pemateri juga menyampaikan tentang tanda-tanda kematian dan cara-cara memandikan jenazah. Materi telah disampaikan secara singkat, padat dan jelas (OPB2 dan Dok.8).

Setelah itu, para santri dibagi menjadi beberapa kelompok untuk melakukan praktik memandikan, mengkafani dan mensalatkan mayat. Selama prantik, Ustā̇̇a Siti Sumarni memberikan arahan dengan baik an bertahap. Kemudian, setiap praktik Ustā̇a setiap kelompok, sehingga jika ada kekeliruan, Ustäza mengklarifikasinya. Kegiatan praktik pun selesai pada pukul 14.30 (OPB2).

Salah satu metode yang digunakan Rasulullah dalam mendidik para sahabatnya adalah dengan latihan, yaitu memberikan kesempatan kepada para sahabat untuk mempraktikkan cara-cara melakukan ibadah secara berulang kali. Metode seperti ini diperlukan oleh pendidik untuk memberikan pemahaman dan membentuk keterampilan peserta didik (Umar, 2010, hal. 191).

\section{g. Evaluasi}

Evaluasi yang dilakukan bukanlah evaluasi seperti anak-anak di sekolah pada umumnya. Evaluasi akhir ini, lebih kepada evaluasi program. Evaluasi ini, berupa angket yang berisi tentang kepuasaan materi pokok dan kepesantrenan, materi pembiasaan, dampak kegiatan dan lain sebagainya. Selain itu, pada angket tersebut para santri PMK harus mengisi manfaat yang dirasakan, kesan dan pesan selama mengikuti kegiatan pendidikan Islam pada program PMK. Dengan adanya angket ini, pihak pelaksana ingin mengetahui seberapa besar kepuasaan santri terhadap kegiatan pendidikan Islam pada PMK, sehingga bisa menjadi input data dari saran yang diberikan (WRB dan Dok.9).

"Evaluasi adalah suatu proses bukan suatu hasil (produk). Hasil yang diperoleh dari kegiatan evaluasi adalah kualitas sesuatu, baik yang menyangkut nilai atau arti, sedangkan kegiatan untuk sampai pada pemberian nilai dan arti adalah evaluasi (Arifin M. , 2009, hal. 56)."

Jadi, hasil yang diperoleh dari kegiatan evaluasi adalah kualitas sesuatu. Dengan adanya evaluasi ini, akan menentukan sebuah kualitas pendidikan Islam pada program PMK. Jika persentase respon yang baik lebih besar, maka kualitas dari kegiatan pendidikan Islam ini dapat dinyatakan baik. Adapun menurut bagian renbang, hasil persentase dari kegiatan evaluasi adalah $80 \%$ mendapatkan respon positif. Artinya, pendidikan Islam pada program PMK memberikan kesan yang sangat baik kepada para santri.

\section{h. Wisuda}

Pada hari ke-40, santri PMK mengikuti kegiatan wisuda. Artinya, kegiatan telah selesai dan santri PMK bisa kembali ke rumahnya masingmasing. Kegiatan wisuda, dilaksanakan hari jum'at tanggal 17 April 2015 pada pukul 08.00 pagi. Rangkaian acaranya dimulai dengan sambutan-sambutan, pelepasan syal dan penyerahan sertifikat, buku kenangan dan review kegiatan serta penyampaian kesan dan pesan. Kegiatan wisuda ini berakhir pada pukul 11.20 yang ditutup dengan do'a dan musafahah (OWA).

Dengan berakhirnya kegiatan, maka resmilah santri PMK angakatan ke-14 menjadi bagian alumni PMK. Khusus bagi para alumni, bisa mengikuti kegiatan PMK kembali tanpa harus membayar. Akantetapi, dengan syarat 
harus memakai syal alumni ketika mengikuti kegiatan PMK. Selain itu, tujuan dibentuknya alumni PMK, untuk mencharge rohani agar tetap istiqamah setelah 40 hari menimba ilmu di Dārut Tarbiyah Dārut Tauhīi Bandung. Adapun kegiatan para alumni adalah silaturahim, ta' lim yang diisi dengan tausiyah dari tim ustāaz DT ataupun luar DT dan melakukan kegiatan M2M khusus muslimah (OWA dan Dok.10).

Tugas perkembangan lansia adalah sebagai berikut (Maryam dkk, 2008, hal. 40) yaitu mempersiapkan diri untuk pensiun, membentuk hubungan baik dengan orang seusianya, mempersiapkan kehidupan baru, melakukan penyesuaian terhadap kehidupan sosial/masyarakat secara santai dan mempersiapkan diri untuk kematiannya dan kematian pasangan.

3. Analisis Hasil Pendidikan Islam pada Program Pesantren Masa Keemasan

Hasil pendidikan Islam pada program PMK yaitu terbangunnya suatu pembiasaan. Hal itu disebabkan karena, para santri dibiasakan bangun lebih pagi untuk melaksanakan salat tahajjud, berangkat ke masjid melaksanakan salat berjamaah, tilawah, puasa, salat rawatib dan salat sunnah lainnya. Selain itu, beberapa Ayah merasa lebih tenang selama mengikuti kegiatan PMK ini. Selain itu, adanya perubahan sikap yang semakin membaik pada diri santri (WMS dan WMH).

Secara keseluruhan hasilyang dirasakan selama mengikuti pendidikan Islam pada program PMK ini adalah bisa memperbaiki yang kurang menjadi lebih baik, bisa mendekatkan diri kepada Allah dengan sebenar-benarnya, bisa melaksanakan pembiasaan ibadah dengan istiqamah, belajar disiplin sehingga tidak menyia-nyiakan waktu, belajar mandiri dan tidak ketergantungan kepada orang lain serta menumbuhkan motivasi agar selalu mendekatkan diri kepada Allah, ada keinginan untuk mempelajari dan menghafal Al-Qur'ān lebih mendalam sebagai upaya untuk mencapai husnul khātimah. Adapula yang mengatakan bahwa belajar di Dārut Tauhīid itu seperti di Madinah, suasana dan lingkungannya itu seperti di Madinah (WS1, WS2, WS3, WS4, WS5, dan WS6).

Adapun ciri-ciri perubahan yang terjadi dalam diri seseorang melalui belajar itu bersifat sengaja, bukan terjadi perubahan yang otomatis, seperti perubahan tingkah laku akibat mabuk, kelelahan, kematangan usia dan sebagainya. Proses belajar yang membawa perubahan tingkah laku menurut pandangan pendidikan Islam, tidak hanya menyangkut perubahan kemampuan rasional, melainkan juga perubahan fungsi kejiwaan lainnya (fungsi perasaan, kemauan, ingatan) (Arifin, 2008, hal. 108).

Bedasarkan hasil wawancara dengan para santri, menyatakan bahwa banyak sekali manfaat yang dirasakan, baik dari segi pengetahuan, sikap ataupun keterampilan. Adapun yang paling dirasa adanya perubahan diri yaitu bagaimana mereka bisa memanage kalbu. Selama ini, mereka merasa selalu bergantung pada manusia, tapi setelah mengetahui bagaimana cara memanajkalbu mereka pun selalu belajar untuk bergantung kepada Allah, lebih berharap ke Allah, lebih cinta pada Allah dan segala sesuatu disandarkan hanya kepada Allah. Selain itu,menyadarkan pula bahwa hati adalah bagian paling penting dari manusia. Jika hati manusia baik, maka baik pula seluruh amal manusia, begitupun sebaliknya. Materi ini sangat berkesan karena, disadari atau tidak penyakit hati selalu muncul dalam diri manusia. Para santri pun selalu berusaha untuk senantiasa mengikis penyakit hati dan diaplikasikan dalam kehidupan seharihari.

Selain dari hasil wawancara, peneliti juga mengamati selama proses pendidikan Islam berlangsung. Adapun hasil pendidikan Islam yang peneliti lihat yaitu sebagai berikut: 
1. Menumbuhkan motivasi agar senantiasa mendekatkan diri kepada Allah sebagai upaya mencapai husnul khātimaћ.

2. Menumbuhkan motivasi dan semangat untuk selalu menambah ilmu, khususnya ilmu agama

3. Terbangun karakter BAIK (Baik dan Kuat) pada santri PMK. Baik yang dimaksud seperti saling menghargai, saling tolong menolong, rendah hati dan lain sebagainya. Sedangkan kuat yang dimaksud adalah disiplin, mandiri dan lain sebagainya

4. Terjalinnya hubungan baik antar sesama santri ataupun dengan lingkungan sekitarnya

Jika berbicara tentang hasil, maka berkesinambungan dengan tujuan. Menurut Darajat (2009, hal. 28) tujuan ialah suatu yang diharapkan tercapai setelah sesuatu atau kegiatan selesai. Adanya pendidikan ini, merupakan suatu usaha dan kegiatan yang berproses melalui tahap-tahap dan tingkatantingkatan, tujuannya bertahap dan bertingkat.

Arifin (2008, hal. 28) menjelaskan bahwa pendidikan Islam bertujuan untuk menumbuhkan pola kepribadian manusia yang bulat melalui latihan kejiwaan, kecerdasan otak, penalaran, perasaan dan indra. Pendidikan harus melayani pertumbuhan manusia dalam semua aspeknya, baik aspek spiritual, intelektual, imajinasi, jasmaniah, ilmiah, maupun bahasanya. Tujuan terakhir dari pendidikan Islam itu terletak dalam realisasi sikap penyerahan diri sepenuhnya kepada Allah, baik secara perorangan, masyarakat, maupun sebagai umat manusia secara keseluruhannya.

Tujuan pendidikan Islam adalah persiapan untuk kehidupan dunia dan akhirat (Daulay, 2009, hal. 7). Adapun pendapat lain menjelaskan bahwa meninggal dunia dalam keadaan berserah diri kepada Allah sebagai muslim yang merupakan ujung dari takwa sebagai akhir dari proses hidup, jelas berisi kegiatan pendidikan. Inilah akhir dan proses pendidikan yang dianggap sebagai tujuan akhirnya. Insan kamil yang meninggal dalam keadaan berserah diri kepada Allah merupakan tujuan akhir dari proses pendidikan Islam (Darajat dkk, 2009, hal. 31).

Tujuan diadakannya PMK, yaitu untuk memfasilitasi para lansia yang ingin mempelajari Islam secara lebih intensif, ingin lebih mendekatkan diri kepada Allah, ingin mempersiapkan diri meraih husnul khātimaћ, serta membentuk menjadai pribagi yang berkarakter baku (baik dan kuat). Semua tujuan ini, dirasakan hasilnya oleh santri PMK. Sebagaimana yang telah dipaparkan diatas, tujuan pasti berkesinambungan dengan hasil. Dengan adanya pernyataan ini, ditegaskan kembali bahwa pendidikan Islam pada program PMK ini cukup berhasil. Hal itu, disebabkan karena hasil yang dirasakan para lansia setelah mengikuti pendidikan Islam pada program PMK telah sesuai dengan tujuan yang diharapkan dari program PMK ini.

\section{KESIMPULAN}

Perencanaan pendidikan Islam apda program PMK sudah cukup baik dan terorganisir. Adapun dalam pelaksanaannya setiap kegiatan terlaksana dengan baik. Selain itu, proses pendidikan bagi lansia, bukan saat penyampaian materi saja. Akan tetapi, ditekankan pula pengamalan dan latihan, yaitu dengan membiasakan salat fardu berjamaah, amalan sunat lainnya dan menerapkan tata budaya dan nilai Dārut Tauhīd. Sedangkan untuk hasil pendidikan Islam sudah cukup sesuai dengan tujuan yang diharapkan. Hasil yang dirasakan adalah adanya perubahan diri baik dari segi wawasan, akhlak ataupun keterampilan. Sehingga sangat memotivasi untuk senantiasa mendekatkan diri kepada Allah dengan harapan husnul khätimaћ. Ada[un 
rekomendaasi dari peneliti, perencanaannya harus lebih inovatif. Sehingga dalam pelaksanaannya pun akan lebih kreatif dan inovatif, akan tetapi relevan dengan lanjut usia.

\section{DAFTAR PUSTAKA}

Arifin. (2008). Ilmu Pendidikan Islam. Jakarta: PT Bumi Aksara.

Arifin, M. (2009). Filsafat Pendidikan Islam. Jakarta: PT Bumi Aksara.

Basrowi, \& Suwandi. (2008). Memahami Penelitian Kualitatif. Jakarta: Rineka Cipta.

Darajat, Z., Dkk (2009). Ilmu Pendidikan Islam. Jakarta: Bumi Aksara.

Daulay, H. P. (2009). Dinamika Pendidikan Islam di Asia Tenggara. Jakarta: Rineka Cipta.

Fathoni, A. (2006). Metodologi Penelitian dan Teknik Penyusunan Skripsi. Jakarta: Rineka Cipta.

Jalaluddin. (2010). Psikologi Agama. Jakarta: Rajagrafindo Persada.

Nata, A. (2012). Ilmu Pendidikan Islam. Jakarta: Kencana.

Ramayulis. (2012). Ilmu Pendidikan Islam. Jakarta: Kalam Mulia.

Sugiyono. (2013). Metode Penlitian Pendidikan. Bandung: Alfabeta.
Sutopo, A. H., \& Arief, A. (2010). Terampil Mengolah Data Kualitatif dengan NVIVO. Jakarta: Prenada Media Group.

Sukardi. (2013). Metodologi Penelitian Pendidikan. Jakarta: PT Bumi Aksara.

Suprijanto. (2008). Pendidikan Orang Dewasa. Jakarta: PT Bumi Aksara.

Syahidin. (2009). Menelusuri Metode Pendidikan dalam al-Qur'an. Bandung: Alfabeta.

Tim Pengembang Ilmu Pendidikan. (2007). Ilmu dan Aplikasi Pendidikan. Bandung: PT. Imtima.

Umar, B. (2010). Ilmu Pendidikan Islam. Jakarta: Amzah..

Yusuf, S., \& Sughandi, N. (2011). Perkembangan Peserta Didik. Jakarta: RajaGrafindo Persada. 